Prosiding Seminar Nasional Teknologi Informasi dan Kedirgantaraan : Transformasi Teknologi untuk Mendukung Ketahanan Nasional, Yogyakarta, 13 Desember 2018

SENATIK 2018, Vol. IV, ISBN 978-602-52742-0-6

DOI: http://dx.doi.org/10.28989/senatik.v4i0.165

\title{
INITIAL MODELLING OF BIRD STRIKE BY NUMERICAL SIMULATION IN VARIED L/D RATIO OF BIRD GEOMETRY Endah Yuniarti ${ }^{1}$, Simon Shindu $\mathbf{H}^{2}$, Sahril Afandi Sitompul ${ }^{3)}$ \\ ${ }^{1,2,3}$ Prodi Teknik Penerbangan, Fakultas Teknologi Kedirgantaraan \\ Universitas Dirgantara Marsekal Suryadarma \\ Komplek Bandara Halim Perdanakusuma, Jakarta 13610, Indonesia \\ Email : ${ }^{1}$ endah.yuniarti13@gmail.com
}

\begin{abstract}
This research studies influence of bird geometry on impact pressures during bird strike, namely Hugoniot and Stagnation pressure through initial modelling by numerical simulations. Bird geometry is capsule or cylinder with hemisphere end. The geometry is simulated with different L/D ratio, 1.4, 1.6, 1.8 and 2.0. Elastic-plastic hydrodynamic material model is used in simulation. Bird model simulations are using lagrangian method and initial velocities are $200 \mathrm{~m} / \mathrm{s}$. The results show variation of L/D ratio provide Hugoniot pressure 10-19 times higher than stagnation pressure in $L / D=1.4,8-18$ times in $L / D=1.6$, 9-17 times in $L / D=1.8$ and 4-16 times in $L / D=2$. Hugoniot pressures show higher in ratio $L / D=1.8$ and lower in ratio $L / D=1.6$. Stagnation pressure show higher in ratio $L / D=2.0$ and lower in ratio $L / D$ 1.4.
\end{abstract}

Keywords: Bird Strike, Numerical Simulation, Bird Geometry, Initial Modelling

\section{Pendahuluan}

Fenomena tabrak burung sering terjadi pada saat operasi pesawat terbang yang dapat menyebabkan kerusakan fatal pada struktur pesawat dan mengancam keselamatan operasi penerbangan. Kerusakan struktur pesawat udara dapat menyebabkan kecelakaan dan korban jiwa. Serta kegagalan pada struktur pesawat komersial akibat tabrak burung menyebabkan kerugian ekonomi bagi pelaku industri penerbangan. Hal tersebut berupa biaya langsung perbaikan struktur pesawat dan kerugian penundaan operasi penerbangan.

Berdasarkan data yang tersedia, industri penerbangan komersial telah mengalami kerugian besar akibat kejadian tabrak burung. Data dari International Bird Strike Committee, 55 kejadian fatal telah terjadi antara tahun 1912 dan 2009, terdapat 108 buah pesawat rusak dan 277 penumpang meninggal. Selama penerbangan militer, korban jiwa dan kerusakan pesawat menunjukkan setidaknya 283 pesawat rusak, menyebabkan 141 kematian antara tahun 1959 dan 1999 [1].

Terkait kerusakan atau kegagalan struktur akibat fenomena tabrak burung rentan terjadi pada struktur permukaan luar pesawat udara. Komponen struktur tersebut berupa nose (8\%), windshield (13\%), engine (44\%), wings (31\%), maupun fuselage (4\%), seperti ditunjukkan pada Gambar 1. Tiga perempat lokasi komponen bird strike melibatkan wing dan engine, tetapi bird strike ini dapat merusak hampir seluruh bagian pesawat [2]. 


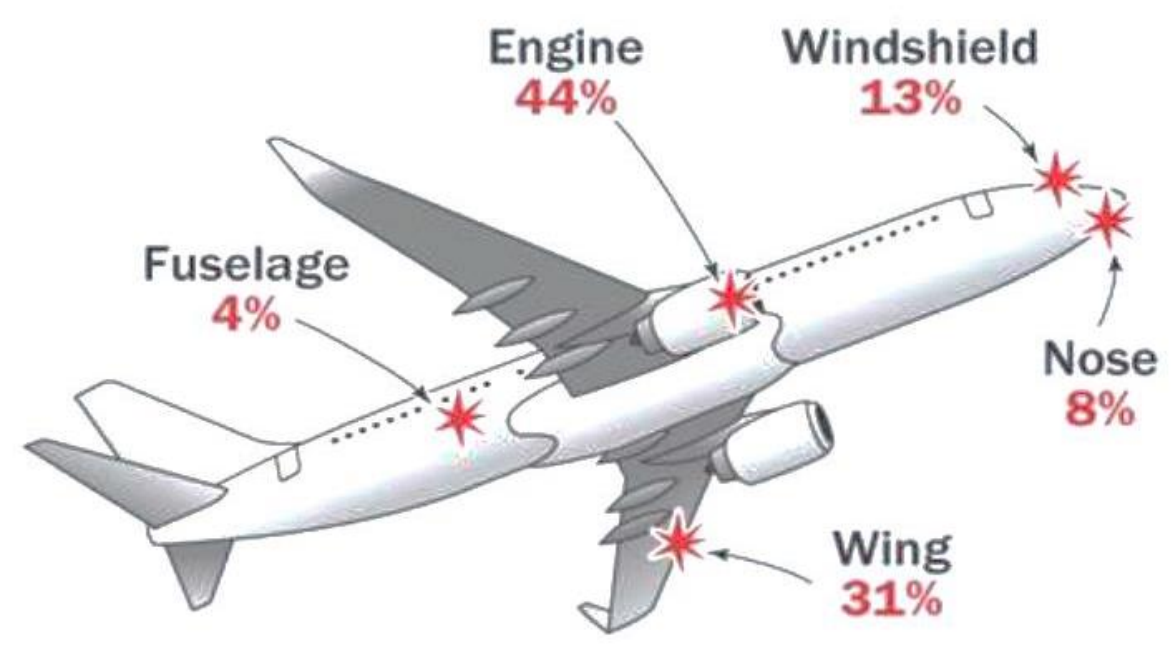

Gambar 1. Ilustrasi komponen struktur pesawat yang rentan terhadap tabrak burung [2]

Biaya kerugian ekonomi yang diderita oleh maskapai penerbangan karena tabrak burung sangat signifikan. Perkiraan total biaya tahunan yang dikeluarkan untuk kasus tabrak burung untuk seluruh dunia penerbangan komersial adalah 1,28 miliar AS. International Bird Strike Committee percaya bahwa jumlah total warga sipil yang tewas dalam kecelakaan yang secara langsung disebabkan oleh kasus tabrak burung setidaknya 242 orang pada tahun 2005 [3]. Kasus tabrak burung terjadi sebagian besar pada fase landing approach (Gambar 2) atau menjelang pendaratan, hal ini dikarenakan biasanya kawanan burung berada pada ladang atau lahan yang luas seperti pada bandara.

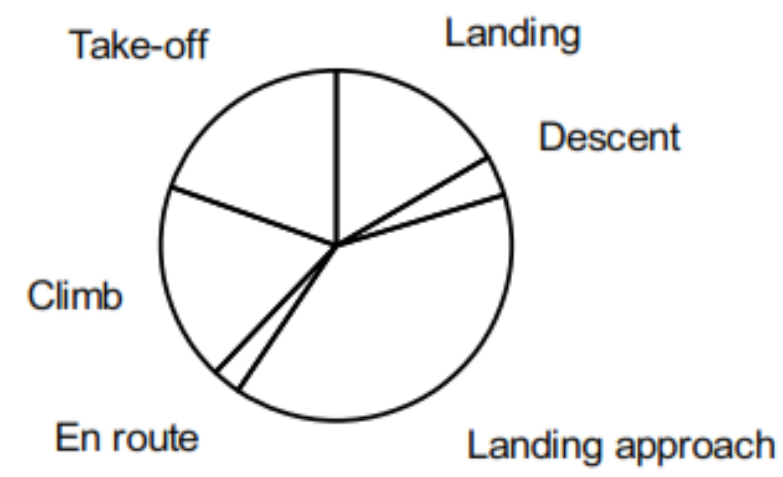

Gambar 2. Fase penerbangan yang sering terjadi kasus tabrak burung [4]

Perancangan yang tahan terhadap bird strike awalnya dilakukan dengan metode eksperimen dan analitik agar dapat memprediksi beban dan tekanan impak burung dan kemungkinan kerusakan atau kegagalan pada beberapa komponen struktur pesawat. Metode eksperimen yang berbiaya besar dan membutuhkan waktu yang lama menjadi tidak praktis bagi pelaku industri pembuatan pesawat. Beberapa penelitian telah mencoba mendekati permasalahan tabrak burung secara analitik, namun memiliki keterbatasan untuk aplikasi geometri yang kompleks dan model material yang nonlinier sehingga jarang digunakan. Perkembangan teknologi komputer yang begitu pesat memudahkan mempelajari fenomena tabrak burung secara numerik (komputasi) sehingga dapat dianalisis secara cepat dan efisien. Oleh karena itu, metode numerik dikembangkan dan diaplikasikan sejak tahun 1970-an dengan tujuan optimasi rancangan guna memastikan sertifikasi uji berhasil dilakukan.

Pemodelan material burung sering menjadi permasalahan utama untuk simulasi numerik tabrak burung. Hal ini karena perilaku material burung yang nonlinear dan geometri 
yang kompleks ketika terjadi kontak dengan komponen struktur. Penggunaan metode numerik dalam penelitian ini memudahkan mempelajari fenomena tabrak burung secara cepat, akurat dan efisien sehingga pemilihan model material dan geometri burung dapat mendekati keadaan secara fisik ketika impak burung terjadi.

Tujuan penelitian ini adalah melakukan simulasi numerik pada kasus bird strike dengan variasi model material dan geometri burung. Simulasi numerik tersebut akan menunjukkan respon dinamik model burung pada kecepatan tinggi berupa gaya impak yang dihasilkan oleh tumbukan burung. Hasilnya akan menjadi jadi acuan dalam perancangan bird strike pada komponen struktur pesawat agar memenuhi standard dan persyaratan yang digunakan pada dunia penerbangan. Pemodelan material dan geometri yang sesuai dengan kondisi fisik akan digunakan selanjutnya dalam simulasi tabrak buruk pada komponen struktur pesawat yang rentan terhadap kasus bird strike, seperti windshield, radome, engine inlet, leading edge. Sehingga proses desain struktur yang tahan terhadap impak dapat dilakukan dengan cepat, akurat serta efisien

\section{Metode Penelitian}

\subsection{Teori Hidrodinamika}

Wilbeck pada tahun 1978 menggabungkan teori analitik tentang persamaan RankineHugoniot, dihubungkan dengan impak pada air dan dengan bukti dari studi eksperimen kasus tabrak burung, sehingga menghasilkan teori fluida pertama tentang tabrak burung secara komprehensif [5,6,7]. Gambar 3 menggambarkan empat fase impak dari sebuah silinder fluida terhadap rigid wall. Geometri yang lebih komplek seperti silinder dengan kedua ujung berupa setengah bola memerlukan teori yang lebih lengkap tetapi pada dasarnya mempunyai perilaku yang sama. Perilaku tumbukan terdiri dari empat tahap: a) sebelum tumbukan b) initial shock saat kontak tumbukan awal, c) release wave, d) aliran deformasi steady.

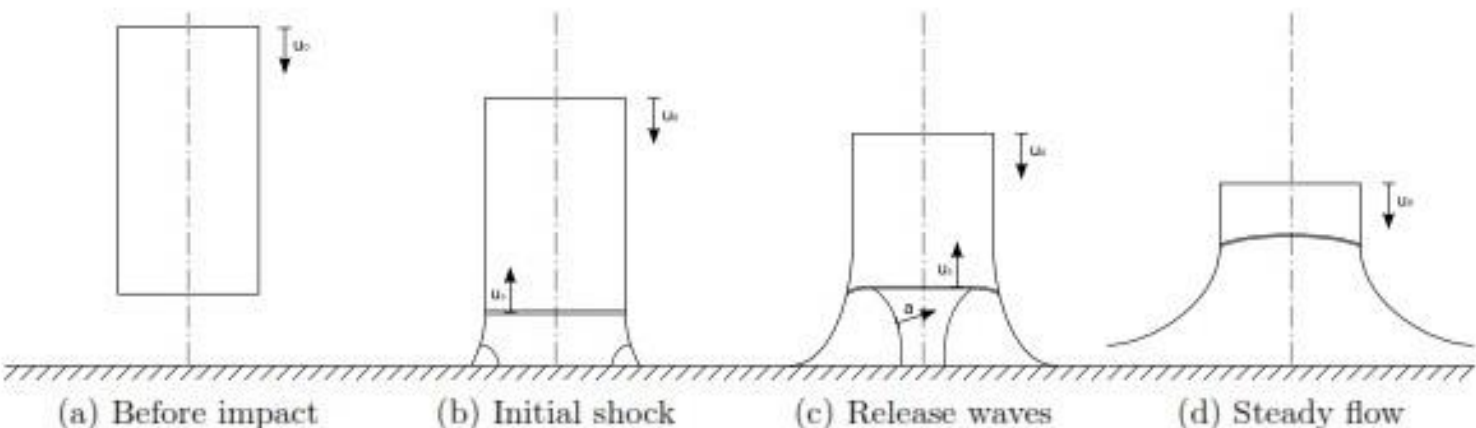
(a) Before impact
(b) Initial shock
(c) Release waves
(d) Steady flow

Gambar 3. Ilustrasi gelombang shock dan release pada tumbukan soft body dengan rigid wall [5]

Grafik tekanan tiap saat pada kasus tumbukan antara soft body dan permukaan rigid ditunjukkan oleh Gambar 4. 


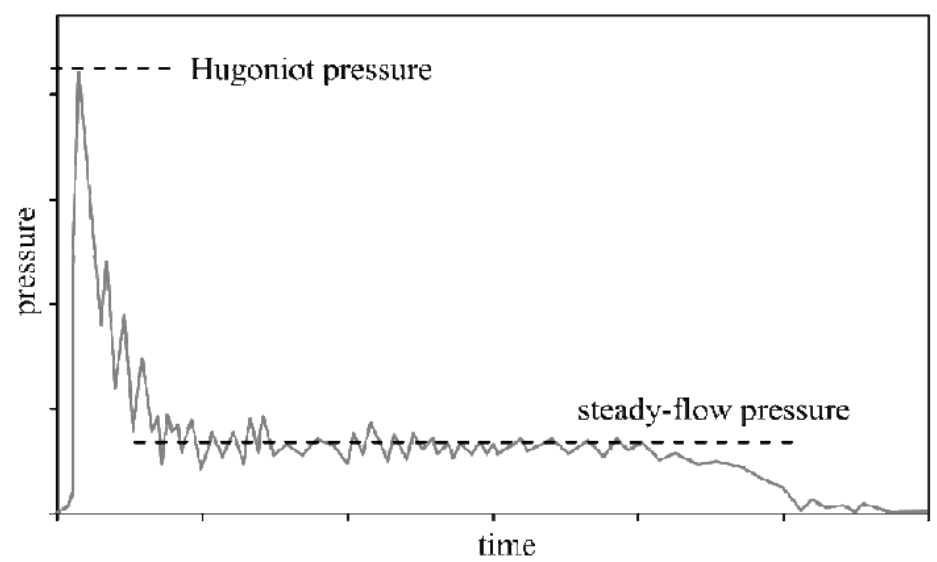

Gambar 4. Kurva tekanan terhadap waktu pada tumbukan soft body dengan permukaan rigid [5]

Tekanan puncak awal pada saat kontak kasus tumbukan tegak lurus bidang disebut dengan Hugoniot Pressure $\left(P_{H}\right)$.

$$
P_{H}=\rho_{0} u_{0} u_{s}
$$

dengan $\rho_{0}$ kerapatan awal impaktor. Tekanan stagnasi $\left(P_{s}\right)$ dapat diformulasikan dengan persamaan Bernoulli:

$$
P_{s}=\frac{1}{2} \rho_{0} u_{0}^{2}
$$

Total durasi saat tumbukan, $t_{\mathrm{D}}$, diperoleh dengan pendekatan waktu yang dibutuhkan impaktor mengalir sepanjang dimensi L impaktor tersebut:

$$
t_{D}=\frac{L}{u_{0}}
$$

\subsection{Metode Elemen Hingga kasus Tabrak Burung}

Metode eksperimen membutuhkan biaya tinggi dan tidak cukup informasi yang diberikan terkait respon struktur pada saat pembebanan. Metode numerik merupakan salah satu upaya untuk mengatasi permasalahan tersebut. Melalui metode numerik penelitian dapat memperoleh kajian data yang berguna seperti distribusi tegangan, perpindahan, serta visualisasi 3D deformasi struktur yang diamati. Metode numerik yang umum digunakan berbasis metode elemen hingga. Pendekatan simulasi untuk tabrak burung yang dilakukan menggunakan Lagrangian Modeling Method, Eulerian Modeling Method, Arbitrary Lagrangian-Eulerian Method (ALE) dan Smooth Particle Hydrodynamics (SPH). Pada penelitian ini metode numerik dengan pemodelan lagrangian dipelajari lebih lanjut.

a) Lagrangian model:

nodes are fixed to the material

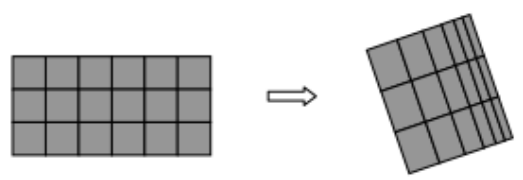

c) ALE model:

Eulerian mesh moves and deforms with material flowing inside
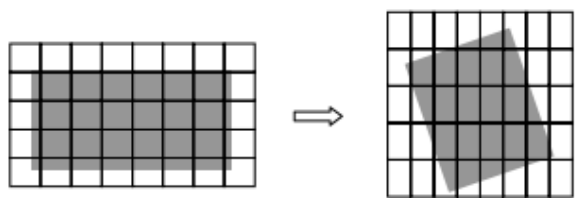

b) Eulerian model:

nodes stay fixed and material flows through the mesh

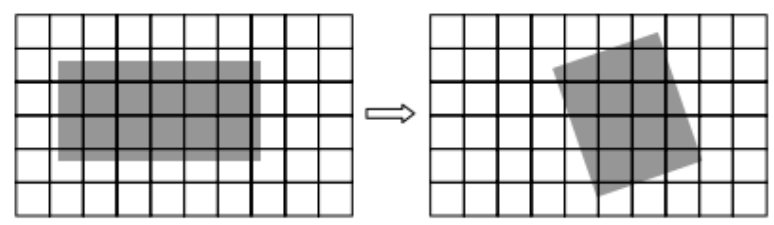

d) SPH model:

fluid is modelled by particles with free motion

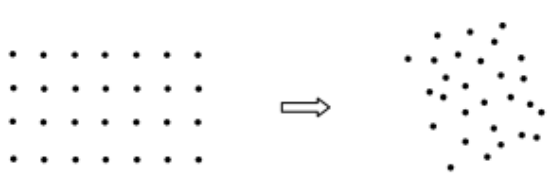

Gambar 5 Pendekatan metode elemen hingga kasus tabrak burung [8] 
Karakteristik metode Lagrangian merupakan salah satu teknik standard pendekatan berbasis metode elemen hingga pada kasus analisis struktur. Nodal pada Lagrangian mesh mewakili material/struktur sehingga masing-masing nodal mengikuti respon struktur ketika terjadi pembebanan, baik berupa gerak maupun deformasi. Kondisi batas terdefinisi dengan jelas dan spesifik.

\subsection{Geometri dan Meshing}

Pada simulasi tabrak burung digunakan pemodelan burung dengan definisi rasio dimensi panjang dan diameter seperti pada Gambar 6 dan nilai dimensi ditunjukkan pada Tabel 1. Pelat memiliki ukuruan $1 \mathrm{~m} \times 1 \mathrm{~m}$ dipilih dan deformasi burung masih terjadi pada pelat hingga simulasi berakhir.

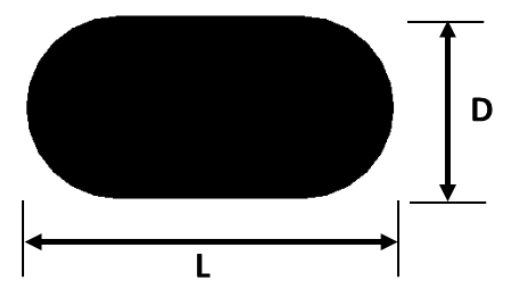

Gambar 6. Definisi geometri model
Tabel 1. Variasi Dimensi

\begin{tabular}{|c|c|c|}
\hline $\begin{array}{c}\text { Ratio } \\
(\mathrm{L} / \mathrm{D})\end{array}$ & $\begin{array}{c}\text { Diameter, D } \\
(\mathrm{m})\end{array}$ & $\begin{array}{c}\text { Panjang, L } \\
(\mathrm{m})\end{array}$ \\
\hline 1.4 & 0.185 & 0.132 \\
\hline 1.6 & 0.200 & 0.125 \\
\hline 1.8 & 0.214 & 0.119 \\
\hline 2 & 0.228 & 0.114 \\
\hline
\end{tabular}

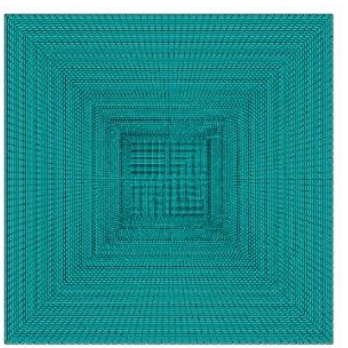

(b)

Gambar 7. Messhing model (a) burung dan (b) pelat

Meshing pada model burung menggunakan jenis elemen linear hexahedral C3D8R dan model pelat dengan jenis elemen Shell Quad S4R, seperti ditunjukkan pada Gambar 7. Ukuran meshing yang digunakan rata-rata $5 \mathrm{~mm}$, digunakan juga pengaturan distortion control dan enhanced hourglass control menggunakan software Abaqus, Simulia [9].

\subsection{Data Material}

Properti material burung yang digunakan ditunjukkan pada Tabel 2. Pada tekanan tinggi, material burung didefinisikan menggunakan properti Equation of State (EOS) yang diinput seperti pada Tabel 3.Pelat didefinisikan sebagai material baja. Data material dan data EOS berdasarkan tabulasi Abaqus [9,10]:

$$
p=+\rho_{0} f_{2}\left(\varepsilon_{v o l}\right) E_{m}
$$

dimana, $f_{1}\left(\varepsilon_{v o l}\right)$ dan $f_{2}\left(\varepsilon_{v o l}\right)$ adalah fungsi dari regangan volumetrik logaritmik $\varepsilon_{v o l}$ saja, dengan $\varepsilon_{v o l}=\ln \rho_{0} / \rho$ dan $E_{m}$ adalah energi internal per unit massa. Kontribusi energi internal terhadap tekanan dalam hal ini biasanya diabaikan ketika berhubungan dengan 
daerah hidrodinamik dari impak, sehingga $f_{2}\left(\varepsilon_{v o l}\right)=0$ dan $p=f_{1}\left(\varepsilon_{v o l}\right)$. Nilai $\varepsilon_{v o l}=$ $\ln \rho_{0} / \rho$ diambil dari kurva tabulasi Abaqus pada Gambar 8 dan untuk kasus zero porosity dirangkum pada Tabel 3. Dimana densitas material burung pada tekanan atsmosfer $\rho_{0}$, yaitu sebesar $938 \mathrm{~kg} / \mathrm{m}^{3}$ [10].

Tabel 2. Data Material [10]

\begin{tabular}{|c|c|c|c|c|}
\hline $\begin{array}{c}\text { Mass } \\
(\mathrm{kg})\end{array}$ & $\begin{array}{c}\text { Density } \\
\left(\mathrm{kg} / \mathrm{m}^{3}\right)\end{array}$ & $\begin{array}{c}\text { Shear Modulus } \\
(\mathrm{GPa})\end{array}$ & $\begin{array}{c}\text { Yield Stress } \\
(\mathrm{MPa})\end{array}$ & $\begin{array}{c}\text { Hydrostatic Cut-off } \\
\text { Stress (MPa) }\end{array}$ \\
\hline 1,8 & 938 & 0,01 & 0,1 & 2,75 \\
\hline
\end{tabular}

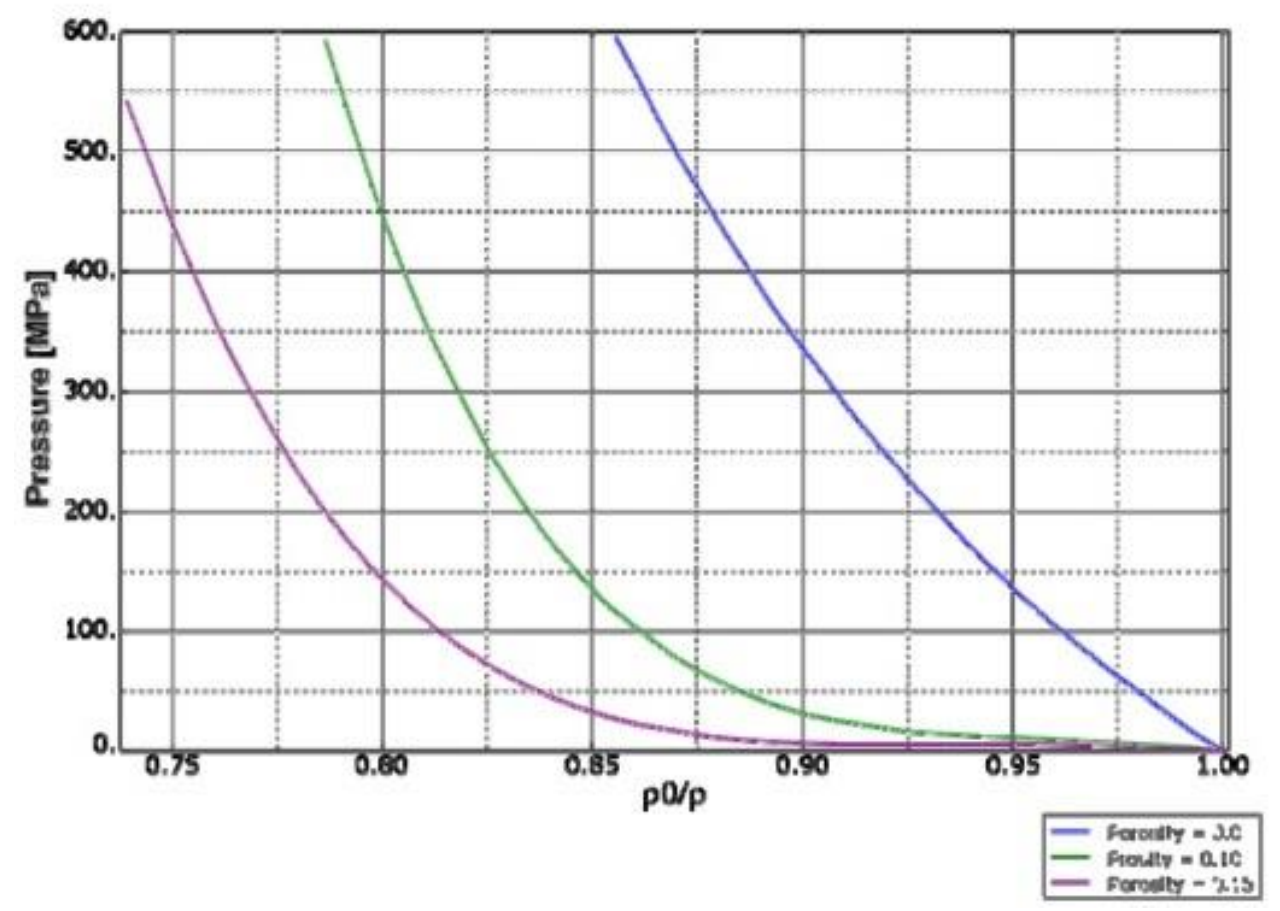

Gambar 8. Hugoniot curves of water-like homogenized bird materials [10]

Tabel 3. EOS [10]

\begin{tabular}{|c|c|c|c|c|c|c|c|}
\hline No. & $\mathrm{f}_{1}(\mathrm{MPa})$ & $\mathrm{f}_{2}$ & $\varepsilon_{\mathrm{vol}}$ & No. & $\mathrm{f}_{1}(\mathrm{MPa})$ & $\mathrm{f}_{2}$ & $\varepsilon_{\mathrm{vol}}$ \\
\hline 1 & 0 & 0 & 0 & 14 & 263.29 & 0 & -0.0878 \\
\hline 2 & 15.82 & 0 & -0.0073 & 15 & 289.34 & 0 & -0.0945 \\
\hline 3 & 32.56 & 0 & -0.0139 & 16 & 315.39 & 0 & -0.1003 \\
\hline 4 & 51.17 & 0 & -0.0209 & 17 & 342.37 & 0 & -0.1071 \\
\hline 5 & 68.85 & 0 & -0.0280 & 18 & 370.29 & 0 & -0.1134 \\
\hline 6 & 87.45 & 0 & -0.0347 & 19 & 399.13 & 0 & -0.1194 \\
\hline 7 & 106.06 & 0 & -0.0415 & 20 & 429.83 & 0 & -0.1258 \\
\hline 8 & 127.46 & 0 & -0.0487 & 21 & 460.53 & 0 & -0.1318 \\
\hline 9 & 147.93 & 0 & -0.0551 & 22 & 493.09 & 0 & -0.1383 \\
\hline 10 & 168.40 & 0 & -0.0616 & 23 & 526.59 & 0 & -0.1444 \\
\hline 11 & 191.66 & 0 & -0.0681 & 24 & 561.01 & 0 & -0.1500 \\
\hline 12 & 213.98 & 0 & -0.0746 & 25 & 595.43 & 0 & -0.1562 \\
\hline 13 & 238.17 & 0 & -0.0812 & & & & \\
\hline
\end{tabular}




\subsection{Kondisi Pembebanan dan Kondisi Batas}

Beban impak diberikan dengan variasi kecepatan awal tumbukan pada burung sebesar $150 \mathrm{~m} / \mathrm{s}, 200 \mathrm{~m} / \mathrm{s}$ dan $250 \mathrm{~m} / \mathrm{s}$. Kondisi batas/tumpuan ditentukan pada bagian sisi-sisi ujung pelat dengan kondisi ditahan (fixed).

\section{Hasil dan Pembahasan}

Hasil deformasi dengan model material yang digunakan dapat dilihat pada Gambar 9. Dimana Gambar 9 tersebut mewakili hasil deformasi untuk contoh model yang lain (semua variasi L/D dan kecepatan awal) karena hasil deformasi yang terjadi hampir sama.

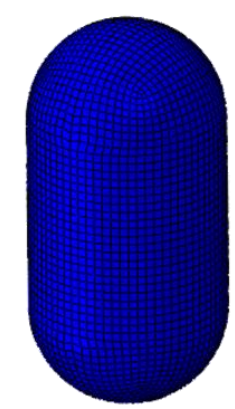

(a)

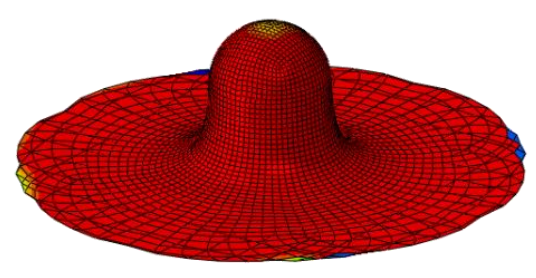

(c)

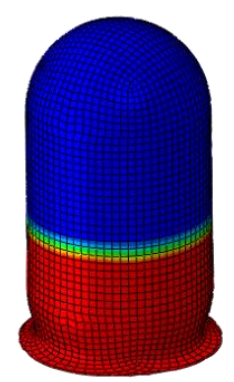

(b)

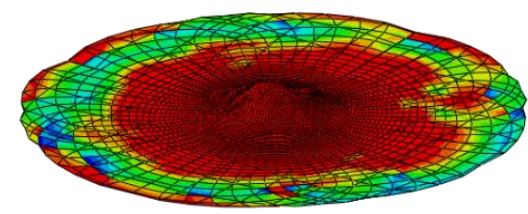

(d)

Gambar 9. Pola deformasi burung rasio L/D $=2$ pada kecepatan $200 \mathrm{~m} / \mathrm{s}$ tiap waktu berikut: (a) $\mathrm{t}=0 \mathrm{~s}$, (b) $\mathrm{t}=6 \mathrm{e}-05 \mathrm{~s}$, (c) $\mathrm{t}=2,8 \mathrm{e}-04 \mathrm{~s}$, (d) $\mathrm{t}=5,6 \mathrm{e}-04 \mathrm{~s}$

Nilai tekanan Hugoniot yang diperoleh dengan cara mengambil data gaya kontak antara burung dan pelat tiap saat dan dibagi dengan area kontak tiap saat. Sementara, nilai tekanan stagnasi diperoleh dengan cara mengintegrasi nilai tekanan pada selang $1 / 3 t_{D}$ hingga $2 / 3 t_{D}$ kemudian dibagi dengan $1 / 3 t_{D}$. Keluaran simulasi tabrak burung berupa grafik tekanan tiap saat ditunjukkan pada Gambar 10 - 21, dimana terlihat bahwa semua grafik memiliki pola grafik tekanan yang sama yaitu tekanan Hugoniot di awal impak. Hasil tekanan Hugoniot dan tekanan stagnasi dirangkum pada Tabel 4 dan Tabel 5.

Nilai tekanan Hugoniot jauh lebih tinggi sekitar 22-32 kali lipat tekanan stagnasi pada $\mathrm{L} / \mathrm{D}=1,4$ (Gambar 10-12). 19-25 kali pada L/D = 1,6 (Gambar 13-15). 18-23 kali pada $\mathrm{L} / \mathrm{D}=1,8$ (Gambar 16-18). 22-26 kali pada L/D = 2 (Gambar 19-21). Nilai tersebut menunjukkan tekanan dapat menjelaskan kegagalan lokal yang terjadi pada kasus tabrak burung. Nilai tekanan Hugoniot menunjukkan nilai tertinggi pada rasio L/D 1,6 pada kecepatan $250 \mathrm{~m} / \mathrm{s}$ yaitu sebesar $873 \mathrm{MPa}$ (Gambar 15) dan nilai terendah pada rasio L/D 1,6 pada kecepatan $150 \mathrm{~m} / \mathrm{s}$ yaitu sebesar $267 \mathrm{MPa}$ (Gambar 13).

Pola grafik tekanan impak terhadap waktu pada Gambar 10 sampai Gambar 21 menunjukkan tekanan sangat tinggi di awal tumbukan dan tekanan tersebut disebut sebagai Tekanan Hugoniot. Fenomena tersebut disebabkan interaksi kontak dan deformasi antara burung dan struktur pesawat yang dikatakan sebagai rigid wall. Saat tumbukan pertama burung dengan rigid wall, tekanan pada titik impak meningkat secara cepat akibat shock 
pressure yang timbul. Saat shock wave merambat pada rigid wall, menyebabkan rigid wall bergerak pada arah yang sama dengan kecepatan awal tumbukan burung, pada saat bersamaan permukaan depan burung mengalami ekspansi dan tekanan pada area kontak menurun. Penurunan gaya impak antara burung dan rigid wall yang terjadi serta kekakuan flexural rigid wall mengurangi kecepatan rigid wall sehingga memperbesar gaya impak. Proses ini berulang hingga interaksi shock wave dari sumber lain menghilangkan tekanan tinggi.

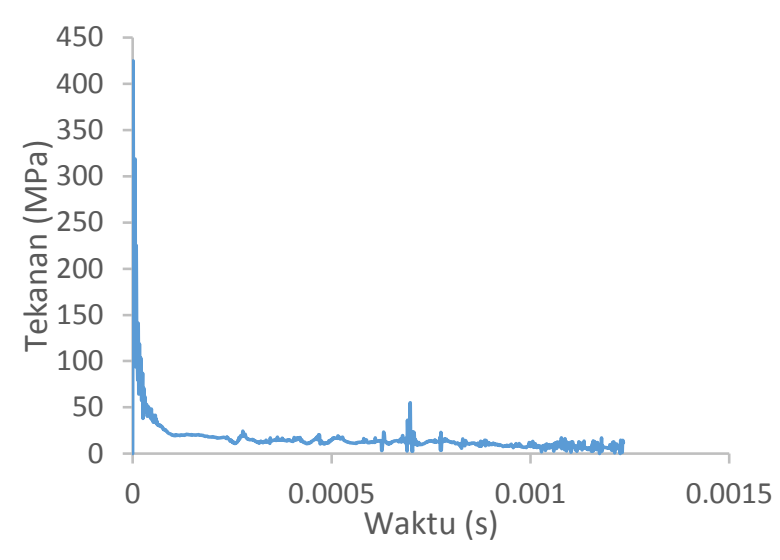

Gambar 10. Tekanan impak terhadap waktu

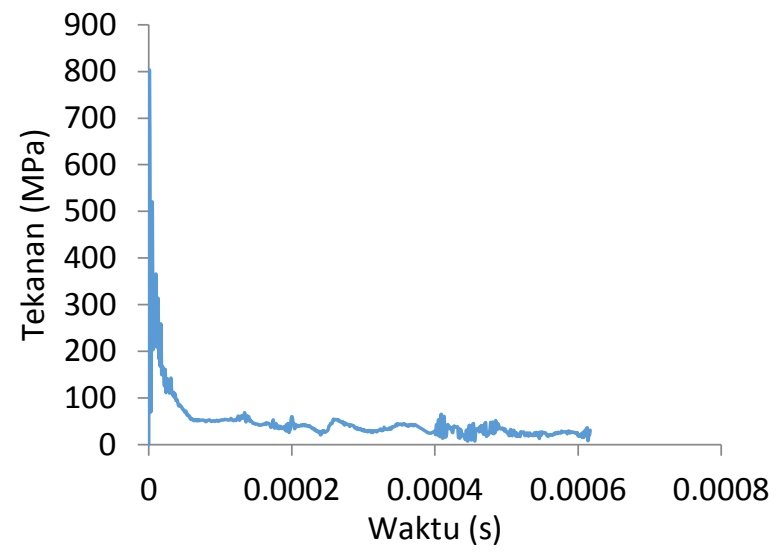

Gambar 12. Tekanan impak terhadap waktu pada kasus rasio $\mathrm{L} / \mathrm{D}=1,4$ pada $\mathrm{v}=250 \mathrm{~m} / \mathrm{s}$

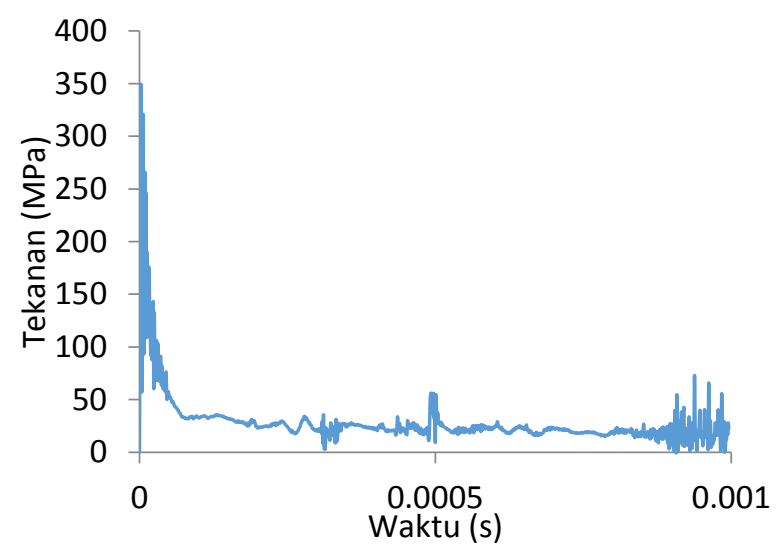

Gambar 14. Tekanan impak terhadap waktu pada kasus rasio $\mathrm{L} / \mathrm{D}=1,6$ pada $\mathrm{v}=200 \mathrm{~m} / \mathrm{s}$

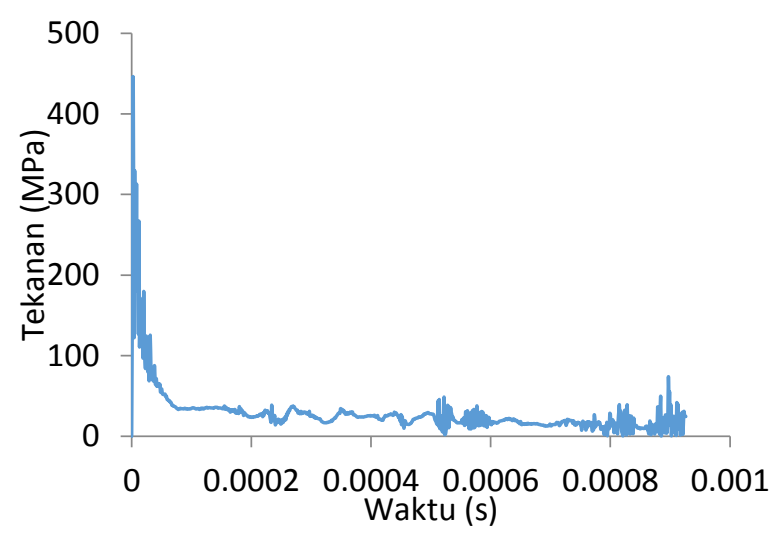

Gambar 11. Tekanan impak terhadap waktu

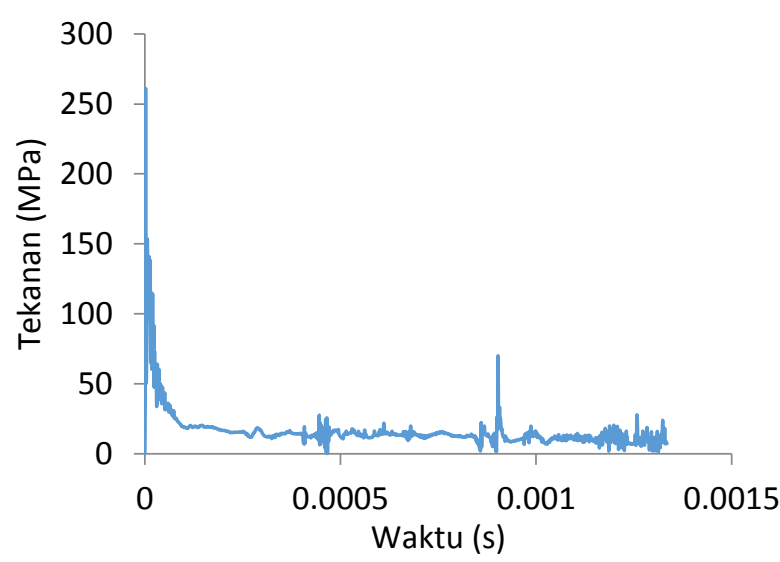

Gambar 13. Tekanan impak terhadap waktu pada kasus rasio $\mathrm{L} / \mathrm{D}=1,6$ pada $\mathrm{v}=150 \mathrm{~m} / \mathrm{s}$

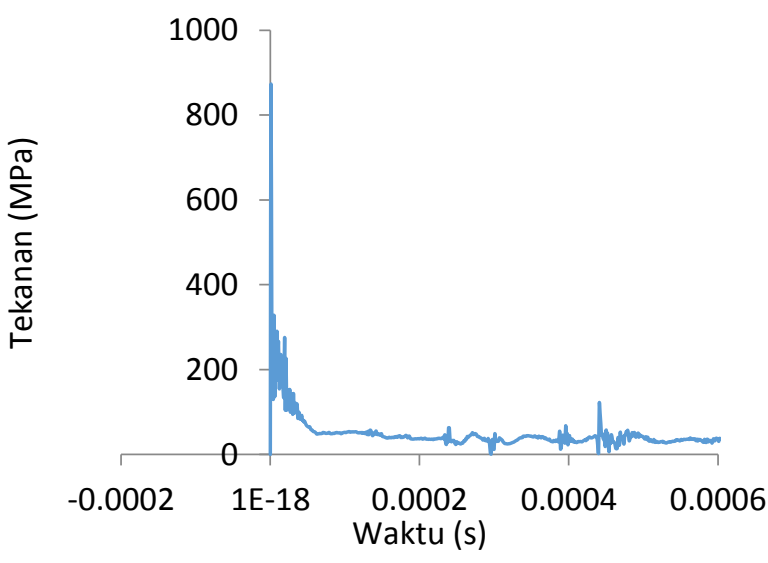

Gambar 15. Tekanan impak terhadap waktu pada kasus rasio $\mathrm{L} / \mathrm{D}=1,6$ pada $\mathrm{v}=250 \mathrm{~m} / \mathrm{s}$ 


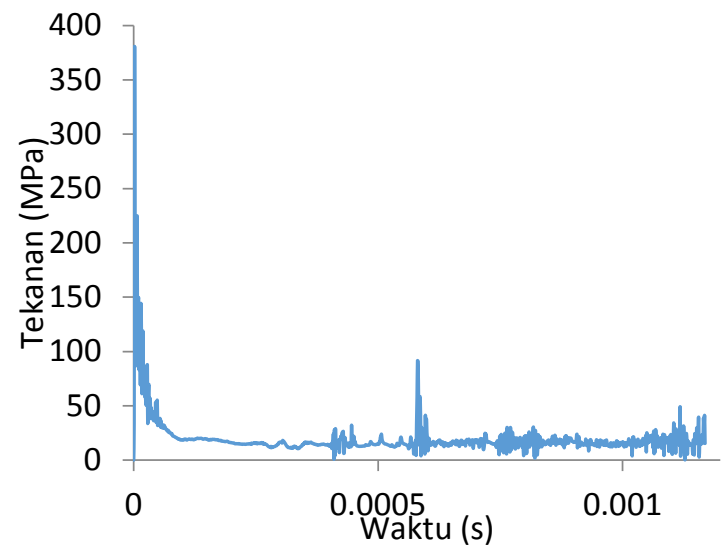

Gambar 16. Tekanan impak terhadap waktu pada kasus rasio $\mathrm{L} / \mathrm{D}=1,8$ pada $\mathrm{v}=150 \mathrm{~m} / \mathrm{s}$

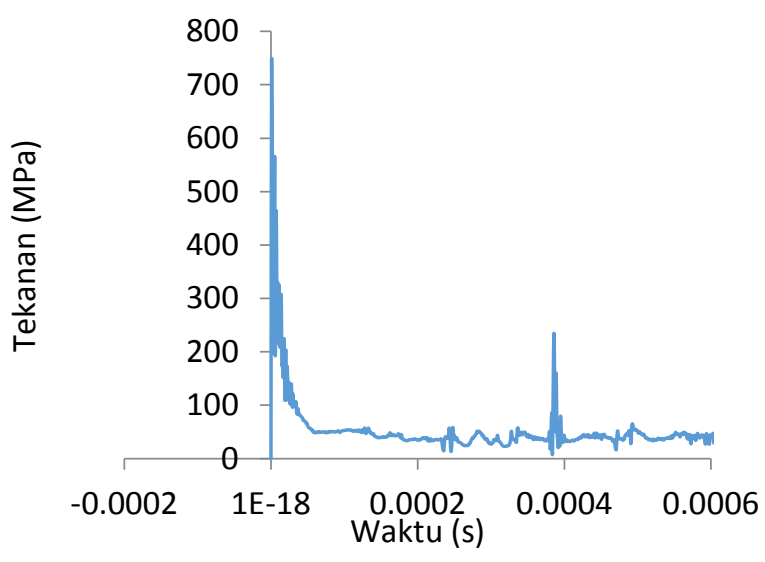

Gambar 18. Tekanan impak terhadap waktu pada kasus rasio $\mathrm{L} / \mathrm{D}=1,8$ pada $\mathrm{v}=250 \mathrm{~m} / \mathrm{s}$

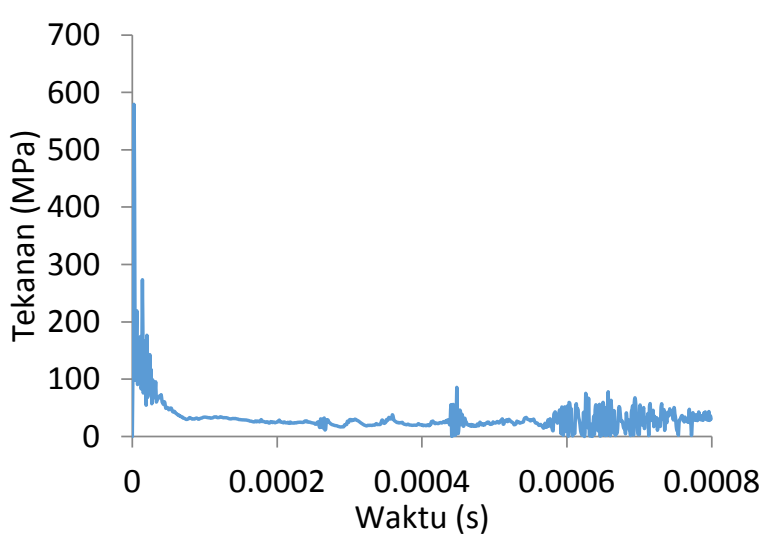

Gambar 20. Tekanan impak terhadap waktu pada kasus rasio $\mathrm{L} / \mathrm{D}=2$ pada $\mathrm{v}=200 \mathrm{~m} / \mathrm{s}$

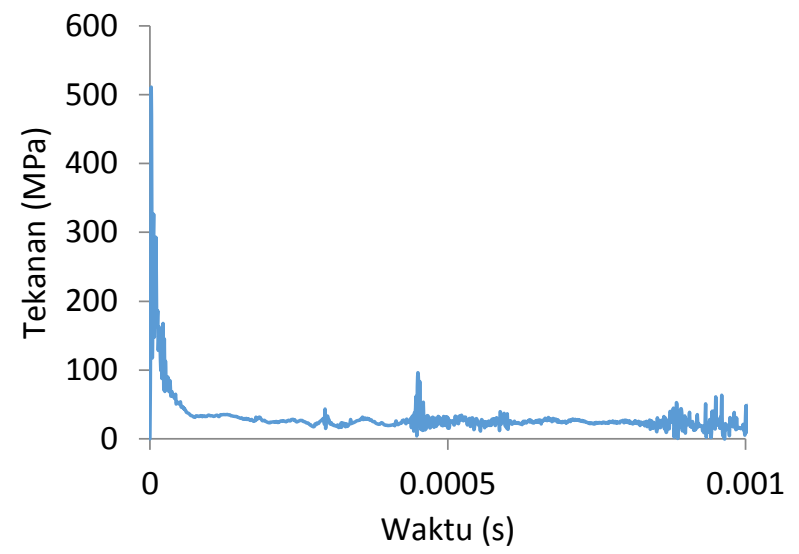

Gambar 17. Tekanan impak terhadap waktu pada kasus rasio $\mathrm{L} / \mathrm{D}=1,8$ pada $\mathrm{v}=200 \mathrm{~m} / \mathrm{s}$

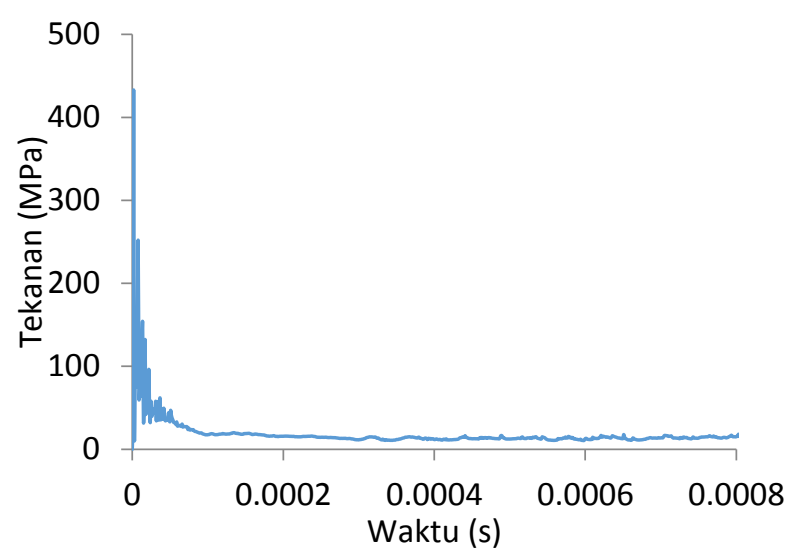

Gambar 19. Tekanan impak terhadap waktu pada kasus rasio $\mathrm{L} / \mathrm{D}=2$ pada $\mathrm{v}=150 \mathrm{~m} / \mathrm{s}$

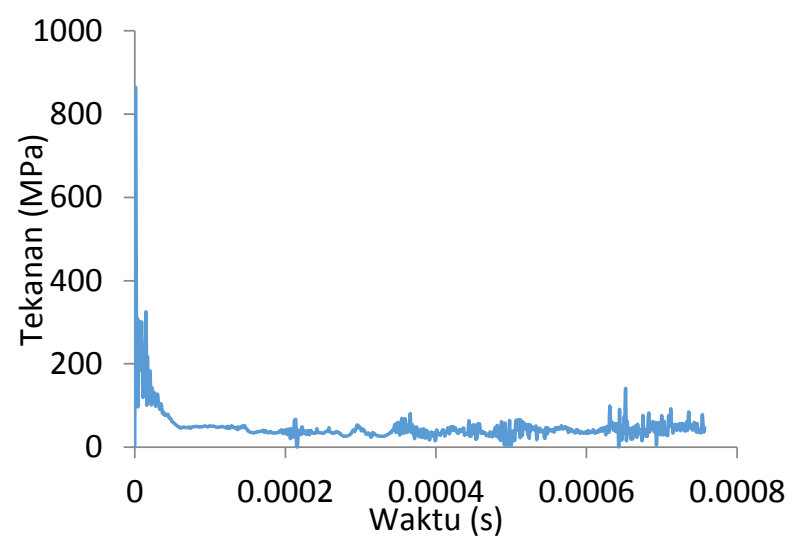

Gambar 21. Tekanan impak terhadap waktu pada kasus rasio $\mathrm{L} / \mathrm{D}=2$ pada $\mathrm{v}=250 \mathrm{~m} / \mathrm{s}$ 
Tabel 4. Hasil Tekanan Hugoniot

\begin{tabular}{|c|c|c|c|}
\hline \multirow{2}{*}{ L/D } & \multicolumn{3}{|c|}{ Tekanan Hugoniot (MPa) } \\
\cline { 2 - 4 } & $\begin{array}{c}150 \\
\mathrm{~m} / \mathrm{s}\end{array}$ & $\begin{array}{c}200 \\
\mathrm{~m} / \mathrm{s}\end{array}$ & $\begin{array}{c}250 \\
\mathrm{~m} / \mathrm{s}\end{array}$ \\
\hline 1.4 & 425 & 446 & 803 \\
\hline 1.6 & 261 & 349 & 873 \\
\hline 1.8 & 381 & 511 & 750 \\
\hline 2 & 433 & 579 & 865 \\
\hline Rata-rata & 375 & 472 & 823 \\
\hline
\end{tabular}

Tabel 5. Hasil Tekanan Stagnasi

\begin{tabular}{|c|c|c|c|}
\hline \multirow{2}{*}{$\mathrm{L} / \mathrm{D}$} & \multicolumn{3}{|c|}{ Tekanan Stagnasi (MPa) } \\
\cline { 2 - 4 } & $\begin{array}{c}150 \\
\mathrm{~m} / \mathrm{s}\end{array}$ & $\begin{array}{l}200 \\
\mathrm{~m} / \mathrm{s}\end{array}$ & $\begin{array}{c}250 \\
\mathrm{~m} / \mathrm{s}\end{array}$ \\
\hline 1.4 & 13.5 & 16.8 & 35 \\
\hline 1.6 & 13.6 & 23.4 & 36.2 \\
\hline 1.8 & 16.6 & 25.6 & 41.3 \\
\hline 2 & 16.7 & 26.2 & 37.6 \\
\hline Rata-rata & 15 & 23 & 38 \\
\hline
\end{tabular}

\section{Kesimpulan}

Nilai tekanan Hugoniot jauh lebih tinggi sekitar 22-32 kali lipat tekanan stagnasi pada $\mathrm{L} / \mathrm{D}=1,4 ; 19-25$ kali pada $\mathrm{L} / \mathrm{D}=1,6 ; 18-23$ kali pada $\mathrm{L} / \mathrm{D}=1,8 ; 22-26$ kali pada $\mathrm{L} / \mathrm{D}=2$. Nilai tersebut menunjukkan tekanan dapat menjelaskan kegagalan lokal yang terjadi pada kasus tabrak burung. Nilai tekanan Hugoniot menunjukkan nilai tertinggi pada rasio L/D 1,6 pada kecepatan $250 \mathrm{~m} / \mathrm{s}$ yaitu sebesar $873 \mathrm{MPa}$ dan nilai terendah pada rasio L/D 1,6 pada kecepatan $150 \mathrm{~m} / \mathrm{s}$ yaitu sebesar $267 \mathrm{MPa}$. Sedangkan nilai tekanan Stagnasi menunjukkan nilai tertinggi pada rasio L/D 1,8 pada kecepatan $250 \mathrm{~m} / \mathrm{s}$ yaitu sebesar 41,3 $\mathrm{MPa}$ dan nilai terendah pada rasio L/D 1,4 pada kecepatan $150 \mathrm{~m} / \mathrm{s}$ yaitu sebesar 13,5 MPa.

\section{Daftar Pustaka}

[1] Allan, J. R., (2000), The costs of bird strikes and bird strike prevention. Human conflicts with wildlife: Econonomic considerations. USDA National Wildlife Research Center Symposia, 147-153

[2] Nicholson, R dan Reed, William, S., (2011), Strategis For Prevention of Biird Strike Events, Aero Magazine, QTR_03, 11, page 17-24, https://www.boeing.com/commercial/aeromagazine/articles/2011_q3/4/

[3] Thorpe, J., (2005), Fatalities and Destroyed Civil Aircraft Due To Bird Strikes 20022004, Technical Report IBSC27/WP II-3, International Bird Strike Commitee, Athens

[4] Blair, A., (2008), Aeroengine Fan Blade Desain Accounting For Bird Strike, Thesis, Departmen Aeronautical and Industrial Engineering, The University of Toronto

[5] Wilbeck, J.S., (1978), Impact behavior of low strength projectiles, Technical Report AFML-TR-77-134, Air Force Materials Laboratories, Air Force Wright Aeronautical Laboratories, Wright Patterson Air Force Base, Ohio 45433

[6] Barber, J.P., Taylor, H.R., dan Wilbeck, J.S., (1978), Bird impact force and pressures on rigid and compliant target, Technical Report AFFDL-TR-77-60, Air Force Flight Dynamics Laboratory

[7] Wilbeck, J.S., Barber, J.P. (1978), Impact bird loading, The Shock and Vibration Bulletin $48,2,115-122$.

[8] Heimbs, S., (2011), Bird Strike Analysis in Aircraft Engineering: An Overview. Advances in Mechanical Engineering Research, Vol 3. Nova Science Publishers, Inc.

[9] Abaqus Analysis User Manual, Equation of State, Section 22.2.1, Version 6.10

[10]SIMULIA, A strategy for bird strike simulations using Abaqus/Explicit. Dassault Sytemes. 